\title{
PELATIHAN BERHITUNG CEPAT DENGAN JARI (JARIMATIKA) PADA SISWA KELAS VII UPT SMP MUHAMMADIYAH 1 MAKASSAR
}

\author{
Sitti Rahmah Tahir ${ }^{*}$ \\ St Nur Humairah Halim ${ }^{2}$ \\ 1,2Prodi Pendidikan Matematika Universitas Muhammadiyah Makassar, Makassar, Indonesia \\ rahmahtahir85@gmail.com ${ }^{\left.1^{*}\right)}$ \\ irahumairah08@gmail.com ${ }^{2}$
}

Kata Kunci:
[Jarimatika,
Berhitung Cepat]

Published by:

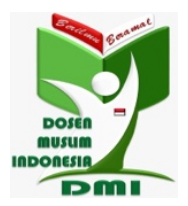

Copyright (C) 2021 The Author(s)

Thisarticleislicensedunder CC BY 4.0 License

\begin{abstract}
Abstrak: Kegiatan pengabdian kepada masyarakat (PKM) ini bertujuan untuk memberikan pengetahuan kepada peserta tentang cara berhitung cepat dengan menggunakan jarimatika sehingga mereka lebih mudah melakukan proses operasi hitung terutama pada materi penjumlahan, pengurangan dan perkalian. Kegiatan ini disamping memperkenalkan jarimatika juga mengajarkan kepada siswa tentang penggunaan jarimatika terkhusus pada operasi penjumlahan, perkalian dan pengurangan. Metode yang digunakan yaitu: (1) Metode observasi untuk mengumpulkan data tentang kemampuan operasi aljabar peserta didik, (2)Metode ceramah ,tanya jawab dan demonstrasi dilakukan pada saat menyajikan materi,(3) Metode pemberian angket untuk mengetahui respon peserta selama kegiatan pelatihan. Peserta kegiatan sebanyak 10 orang yang merupakan peserta didik kelas VII, jumlah yang sangat terbatas karena diakibatkan oleh Pandemi Covid-19, siswa tatap muka dengan metode roling. Peserta pelatihan antusias selama kegiatan berlangsung. Hasil pengabdian ini adalah: (1) peserta didik memahami formasi jari tangan dan aturan penjumlahan, pengurangan dan perkalian dengan menggunakan jarimatika; (2) peserta didik merasa lebih mudah dan lebih cepat dalam menghitung operasi hitung aljabar dengan menggunakan jarimatika; (3) peserta didik memberikan respon positif terhadap kegiatan pelatihan ini. Pelatihan ini mempermudah peserta didik melakukan operasi hitung aljabar dengan menggunakan jari tangan tanpa harus menggunakan metode konvensional.
\end{abstract}

(cc) $\mathrm{BY}$

https://dmi-journals.org/jai/ 


\section{Pendahuluan}

Pendidikan adalah suatu usaha sadar dan terencana untuk menciptakan suasana belajar dan proses pembelajaran agar siswa secara aktif mengembangkan potensi dirinya untuk memiliki kekuatan spiritual keagamaan, pengendalian diri, kepribadian, kecerdasan, akhlak mulia, serta keterampilan yang di perlukan dirinya, masyarakat, bangsa dan negara.Pendidikan dianggap suatu investasi yang paling berharga dalam bentuk peningkatan kualitas sumber daya manusia untuk pembangunan suatu bangsa.Bangsa yang besar dapat diukur dari kualitas masyarakatnya dalam mengenyam pendidikan.Semakin tinggi pendidikan yang dimiliki oleh suatu masyarakat, maka semakin majulah bangsa tersebut. Pendidikan nasional berfungsi mengembangkan kemampuan dan membentuk watak serta peradaban bangsa yang bermartabat dalam rangka mencerdaskan kehidupan bangsa, bertujuan untuk berkembangnya potensi siswa agar menjadi manusia yang beriman dan bertaqwa kepada Tuhan Yang Maha Esa, berakhlak mulia, sehat, berilmu, cakap, kreatif, mandiri, dan menjadi warga negara yang demokratis serta bertanggung jawab.

Salah satu pengetahuan dalam pendidikan yang mampu mengembangkan daya pikir manusia adalah pengetahuan matematika. Matematika merupakan bidang studi yang terdapat di seluruh jenjang pendidikan, baik itu dari taman kanak-kanak hingga ke perguruan tinggi. Belajar matematika sangat diperlukan agar siswa berpikir secara logis dan kritis serta memiliki kemampuan dalam menyelesaikan berbagai masalah dalam kehidupan sehari-hari.Suhendri (2011:32) mengemukakan bahwa matematika ialah ilmu yang mempelajari suatu angka (bilangan), bangun-bangun, konsep, prinsip, hubungan dan logika untuk menyelesaikan suatu permasalahan yang terdapat dalam kehidupan sehari-hari dengan menggunakan bahasa lambang atau biasa juga disebut dengan simbol.

Salah satu mata pelajaran yang menjadi prioritas dan perhatian bagi pemerintah saat ini adalah pelajaran matematika, terbukti dengan adanya peningkatan durasi waktu jam pelajaran yang lebih banyak dibandingkan dengan mata pelajaran lain.Sudah bukan menjadi rahasia umum di lingkungan sekolah, bagi siswa, pelajaran matematika dianggap momok paling menakutkan yamg membuat siswa mengalami kesulitan dalam belajar.Dalam menghadapi soal matematika para siswa dituntut untuk terlebih dahulu melakukan interpretasi terhadap soal yang disuguhkan sebagai landasan dalam menyelesaikan soal tersebut.Selain itu, dalam menyelesaikan soal matematika, siswa juga di tuntut untuk menggunakan keterampilan mengaplikasikan konsep-konsep dalam berbagai soal yang berbeda-beda.

Peningkatan mutu matematika yaitu dengan mempelajari hal yang mendasar dalam matematika (Jana \& Rahmawan, 2019). Keterampilan dasar menjadi standar minimal bagi peserta didik di sekolah menengah untuk melanjutkan ke jenjang yang lebih tinggi. Salah satu keterampilan dasar yang harus dimiliki peserta didik pada jenjang menengah adalah operasi penjumlahan, pengurangan dan perkalian. Materi ini sebenarnya telah diperkenalkan kepada peserta didik pada jenjang kelas III SD, namun sesuai realita yang ada di bangku sekolah menengah masih terdapat siswa yang belum mahir melakukan operasi bilangan. Materi ini sangat penting karena merupakan prasyarat untuk mempelajari materi berhitung selanjutnya. Metode Jarimatika adalah singkatan dari jari dan aritmatika adalah metode berhitung dengan menggunakan jari tanganyang dikembangkan oleh Septi Peni Wulandari. Metode ini dikembangkan pada 
tahun 2000 sampai 2003 dan kemudian mulai dipublikasi pertama kali pada tahun 2003 dalam buku jarimatika. Meski hanya menggunakan jari tangan, tapi dengan metode ini mampu melakukan operasi bilangan KaBaTaKu (kali, bagi, tambah, kurang).

Berdasarkan observasi awal pada sekolah mitra, hasil wawancara guru matematika menunjukkan bahwa sebagian besar peserta didik belum terlalumahir dalam melakukan operasi hitung aljabar dan belum menghafal perkalian dasar. Walaupun guru matematika sudah memberikan daftar perkalian untuk dihafalkan, namun masih banyak yang belum mampu menghafal. Kondisi pandemi yang mengharuskan study from home (belajar dari rumah) membuat guru kesulitan untuk mengecek sampai sejauh mana peserta didik sudah mampu menguasai operasi hitung aljabar. Hal ini karena pembelajaran online tidak berjalan lancar yang disebabkan minimnya penguasaan peserta didik dalam menggunakan aplikasi daring dan keterbatasan peserta didik dalam memenuhi kuota internet. Selain itu, tidak semua peserta didik memiliki android yang dapat mendukung pembelajaran online. Pada sekola mitra juga diadakan skolah tatap muka, namun ini juga kurang maksimal karena peserta didik hadir dengan system roling dan waktu yang sangat terbatas. Olehnya itu diperlukan suatu metode untuk memudahkan peserta didik dalam melakukan proses operasi hitung terutama pada proses perkalian. Dalam hal ini pengabdi akan memberikan pelatihan secara langsung yaitu tentang penggunaan jarimatika. Jarimatika merupakan singkatan dari jari dan matematika yaitu cara berhitung matematika untuk anak-anak dengan menggunakan jari tangan yang dikembangkan oleh Septi Peni Wulandani. Wulandani (2008) mengungkapkan bahwa jarimatika adalah teknik berhitung mudah dan menyenangkan.

Tujuan pengabdian ini adalah agar peserta didik memperoleh pengetahuan tentang operasi hitung dengan menggunakan jarimatika sehingga mereka lebih mudah melakukan proses operasi penjumlahan, pengurangan dan perkalian. Kegiatan pengabdian ini memperkenalkan penggunaan jarimatika pada operasipenjumlahan, pengurangan dan perkalian. Manfaat kegiatan ini adalah peserta didik dapat dengan mudah melakukan operasi bilangan dan dapat dengan mudah mengahafal perkalian dasar dengan menggunakan jari tangan tanpa harus menghafal dengan metode konvensional.

\section{MetodePelaksanaan}

Pengabdian dilaksanakan di UPT SMP Muhammadiyah 1 Makassar tepatnya di jalan Maccini sawah I No.12, Maccini Kelurahan Rappocini Kota Makassar pada hari kamis Tanggal 01 April 2021. Kegiatan ini dilakukan secara langsung (tatap muka) dengan memperhatikan protokol kesehatan. Kegiatan ini dilakukan dengan berkolaborasi bersama mahasiswa bimbingan Program Pemantapan Profesi Keguruan (P2K) Univgggsersitas Muhammadiyah Makassar yang mana dalam hal ini, kami berdua merupakan dosen pembimbing dari mahasiswa P2K tersebut. Sasaran kegiatan ini adalah peserta didik kelas VII pada sekolah mitra. Penentuan peserta didik yang akan mengikuti pelatihan atau pembinaan ini dilakukan dengan terlebih dahulu meminta data dari sekolah mengenai peserta didik dan pertimbangan guru mata pelajaran serta kesedian orang tua untuk memberikan izin kepada anaknya mengingat pengabdian ini dilaksanakan pada masa pandemi.

Metode yang digunakan pada kegiatan ini antara lain: (1) Metode observasi, dilakukan dengan melakukan wawancara terhadap guru mata pelajaran untuk 
mengumpulkan data tentang kemampuan operasi hitung peserta didik, (2) Metode ceramah dan demonstrasi dilakukan pada saat menyajikan materi jarimatika, (3) Metode pemberian angket dilakukan setelah penyampaian materi untuk mengetahui respon peserta didik selama kegiatan pelatihan berlangsung.

Kegiatan pengabdian yang dilaksanakan terbagi menjadi tiga tahap utama, yaitu tahap persiapan, tahap pelaksanaan dan tahap evaluasi. Kegiatan yang dilakukan pada tahap persiapan antara lain: melakukan survey dan observasi pada lokasi dan sasaran, berkoordinasi dengan kepala sekolah dan guru mata pelajaran sebagai tempat dilaksanakannya kegiatan pengabdian, Menyusun bahan materi pelatihan. Kemudian pada tahap pelaksanaan dilakukan kegiatan pelatihan yaitu dengan memberikan penjelasan tentang cara menentukan hasil penjumlahan, pengurangan dan perkalian bilangan dengan menggunakan jarimatika. Tahap selanjutnya adalah tahapevaluasi. Kegiatan yang dilakukan adalah pemberian angket kepada peserta didik yang menjadi peserta pelatihan untuk mengetahui atau mengukur seberapa besar respon peserta setelah mengikuti pelatihan. Indikator keberhasilan kegiatan ini adalah apabila 70\% peserta didik memberikan respon positif terhadap kegiatan ini berdasarkan angket yang dibagikan. Selain itu, kemampuan peserta didik dalam menentukan hasil penjumlahan, pengurangan dan perkalian bilangan juga diharapkan meningkat. Hal ini dapat dilihat pada saat proses tanya jawab dan pemberian soal setelah pemberian materi selesai.

\section{Hasil dan Pembahasan}

Pelatihan jarimatika ini dilaksanakan sesuai dengan jadwal yang telah ditentukan bersama dengan pihak terkait, dengan teknis pelaksanaan adalah pelatihan secara langsung (tatap muka) dengan tetap mematuhi protokol kesehatan. Pelatihan ini mampu memberikan pengetahuan dasar kepada peserta didik tentang bagaimana menentukan hasil penjumlahan, pengurangan dan perkalian dengan mnggunakan jari-jari tangan. Metode pembelajaran menggunakan jarimatika merupakan konsep belajar yang dapat membantu guru dalam menyampaikan materi dengan mudah, serta akan membantu siswa senang melakukan pembelajaran. Materi yang sebelumnya difahami siswa dengan sulit, setelah adanya metode jarimatika ini menjadi lebih mudah. Dari hasil tes siswa jika diamati minat belajar matematika dengan menggunakan metode jarimatika lebih antusias serta mudah memahami penjumlahan, pengurangan dan perkalian. Berikut sajian materi penjumlahan, pengurangan dan perkalian dengan menggunakan metode jarimatika.

\section{Penggunaan jaritmatika dalam penjumlahan dan pengurangan}

Untuk tahap awal yaitu perkenalkan angka-angka menggunakan jari-jari tangan. Sedikit gambaran Teknik Dasar Jarimatika untuk Penjumlahan dan Pengurangan : Jari Tangan Kanan sebagai satuan (Sumber, Sudan 2013)

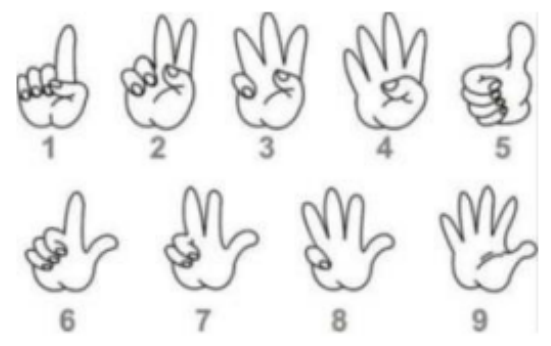




\section{Vol. 1. No. 3. November 2021}

Jari tangan kiri sebagai puluhan


- Penjumlahan

$3+4=7$
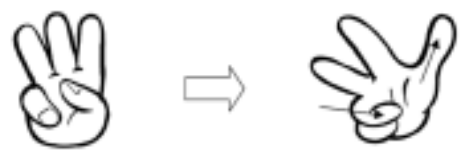

cara: Buka jari kanan 3 kemudian buka lagi 4, karena sudah tidak cukup maka untuk memperoleh angka 4 buka jari jempol yang memiliki angka 5. Karena jempol memiliki angka 5 maka tutup/kurang satu jari untuk mendapatkan 4 .

$9+3=12$

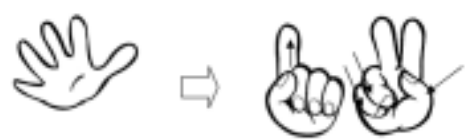

cara: Buka jari kanan 9 kemudian buka lagi 3, karena jari kiri sudah tidak cukup maka untuk memperoleh angka 3 buka jari kiri satu yang memiliki angka 10. Karena satu jari kiri memiliki angka 10 maka tutup/kurang tujuh jari kanan untuk mendapatkan 3.

$8+7=15$



cara: Buka jari kanan 8 kemudian buka lagi 7, karena jari kiri sudah tidak cukup maka untuk memperoleh angka 7 buka jari kiri satu yang memiliki angka 10. Karena satu jari kiri memiliki angka 10 maka tutup/kurang tiga jari kanan untuk mendapatkan 7.

$27+9=36$

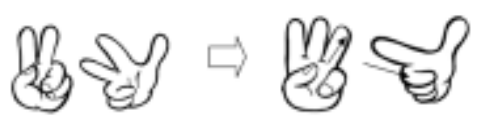

cara: Buka jari kiri 2 kemudian buka jari kanan 7 lalu tambah 9, karena jari kiri sudah tidak cukup maka untuk memperoleh angka 9 buka lagi satu jari kiri yang memiliki angka 10. Karena satu jari kiri memiliki angka 10 maka tutup/kurang satu jari kanan untuk mendapatkan 9. 
- Pengurangan

$7-3=4$

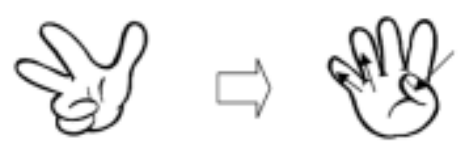

cara: Buka jari kanan 7 kemudian tutup/kurang 3 dengan cara tutup jempol, karena jempol memiliki angka 5 maka untuk memperoleh 3, tutup jempol lalu buka dua jari kanannya.

$24-8=16$

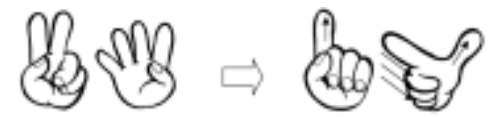

cara: Buka jari kanan 2 dan jari kiri 4 kemudian tutup/kurang 8 dengan cara tutup empat jari kanan, karena masih kurang empat maka tutup lagi satu jari kiri, karena satu jari kiri memiliki angka 10 maka dikurangi empat dan sisa enam, sehingga buka jari kanan 6.

- Penjumlahan dan Pengurangan

$1+5+2-5=3$

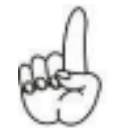

1

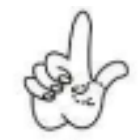

5

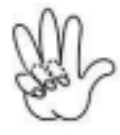

2

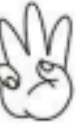

3

$21+13-2=32$

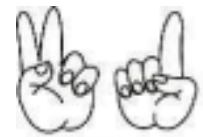

21

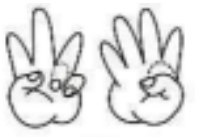

13

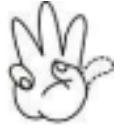

5

$21+55=76$

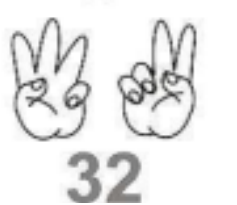

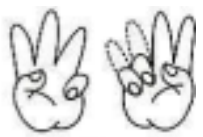

2

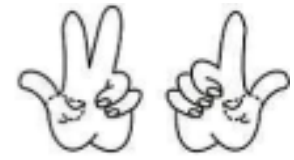

55

21

$+$

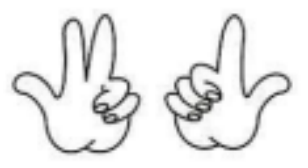

76 


\section{Penggunaan jaritmatika dalam Perkalian}

Konsep Dasar



Bimbingan belajar brilian September 2019

Perkalian dengan jari ini akan membahas perkalian angka-angka 6 sampai 9

$>$ Jari kelingking berperan sebagai angka 6

$>$ Jari manis berperan sebagai angka 7

$>$ Jari tengah berperan sebagai angka 8

$>$ Jari telunjuk berperan sebagai angka 9

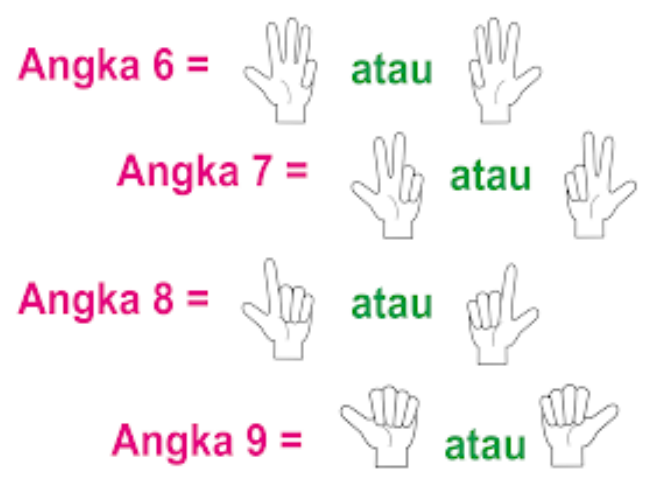

Gambar Posisi Jari - Jarimatika

Aplikasi Perkalian Jaritmatika

PERKALIAN 6 X 6 - JARIMATIKA

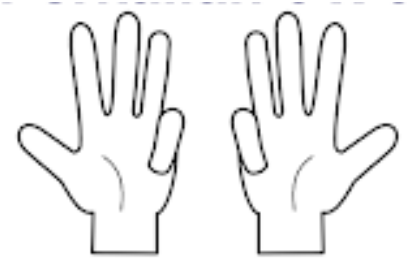

Gambar Jarimatika - Perkalian 6 x 6 


\section{Langkah-Langkahnya:}

Ke-1: Hitung jari yang terlipat ke bawah, setiap jari yang dilipat bernilai 10 .

Gambar tangan di atas terdapat 2 jari terlipat ke bawah, berarti bernilai 20 .

Ke-2: Hitung jari yang tidak terlipat, lalu kalikanlah jumlah jari tangan kanan dan kiri.

Gambar tangan di atas ada 4 jari kiri dan 4 jari kanan, maka $=4 \times 4=16$.

Ke-3: Jumlahkan langkah ke 1 dan ke 2, jadi $=20+16=36$.

\section{PERKALIAN 6 X 7 - JARIMATIKA}

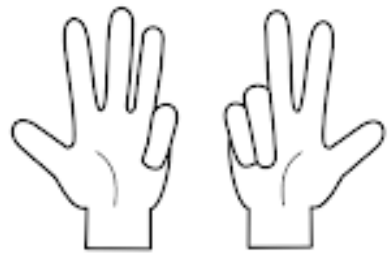

Gambar Jarimatika - Perkalian 6 x 7

\section{Langkah-Langkahnya:}

Ke-1: Hitung jari yang terlipat ke bawah, setiap jari yang dilipat bernilai 10 .

Gambar tangan di atas terdapat 3 jari terlipat ke bawah, berarti bernilai 30.

Ke-2: Hitung jari yang tidak terlipat, lalu kalikanlah jumlah jari tangan kanan dan kiri.

Gambar tangan di atas ada 4 jari kiri dan 3 jari kanan, maka $=4 \times 3=12$.

Ke-3: Jumlahkan langkah ke 1 dan ke 2, jadi $=30+12=42$.

\section{PERKALIAN 6 X 8 - JARIMATIKA}

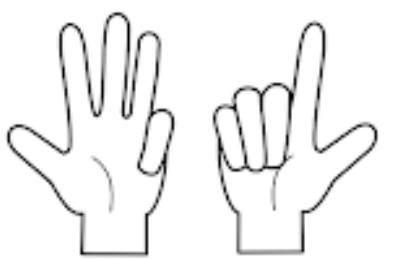

Gambar Jarimatika - Perkalian 6 x 8

\section{Langkah-Langkahnya:}

Ke-1: Hitung jari yang terlipat ke bawah, setiap jari yang dilipat bernilai 10 .

Gambar tangan di atas terdapat 4 jari terlipat ke bawah, berarti bernilai 40 .

Ke-2: Hitung jari yang tidak terlipat, lalu kalikanlah jumlah jari tangan kanan dan kiri.

Gambar tangan di atas ada 4 jari kiri dan 2 jari kanan, maka $=4$ x $2=8$.

Ke-3: Jumlahkan langkah ke 1 dan ke 2 , jadi $=40+8=48$.

\section{PERKALIAN 6 X 9 - JARIMATIKA}

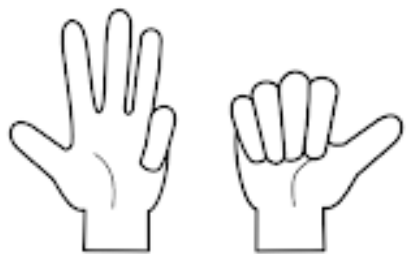

Gambar Jarimatika - Perkalian 6 x 9 


\section{Langkah-Langkahnya:}

Ke-1: Hitung jari yang terlipat ke bawah, setiap jari yang dilipat bernilai 10 .

Gambar tangan di atas terdapat 5 jari terlipat ke bawah, berarti bernilai 50 .

Ke-2: Hitung jari yang tidak terlipat, lalu kalikanlah jumlah jari tangan kanan dan kiri.

Gambar tangan di atas ada 4 jari kiri dan 1 jari kanan, maka $=4 \times 1=4$.

Ke-3: Jumlahkan langkah ke 1 dan ke 2 , jadi $=50+4=54$.

Setelah pengabdi menjelaskan beberapa contoh soal dari masing masing operasi di atas, selanjutnya pengabdi memberikan beberapa soal penjumlahan, pengurangan dan perkalian dasar untuk mengukur penguasaan peserta didik dalam menggunakan jarimatika. Peserta didik terlihat sangat antusias menjawab soal yang diberikan walaupun masih ada beberapa yang kadang masih bingung dengan formasi jarinya. Tetapi secara umum peserta didik hampir semuanya memahami jarimatika. Antusiasme mereka terlihat pada saat mereka meminta soal lagi kepada pengabdi.
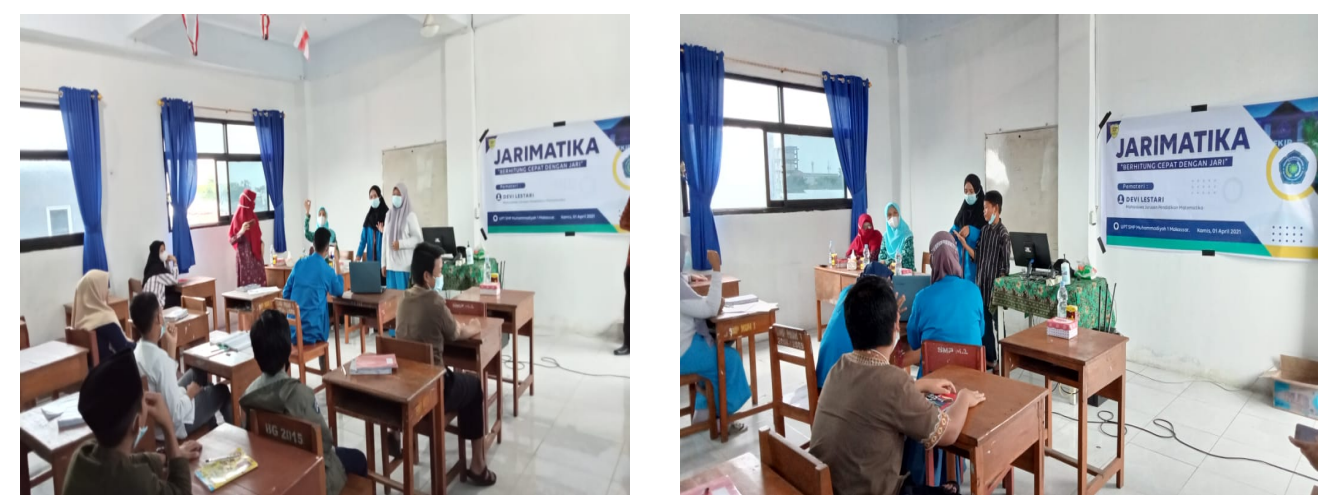

Gambar 1. Peserta Didik Mempraktikan Jarimatika

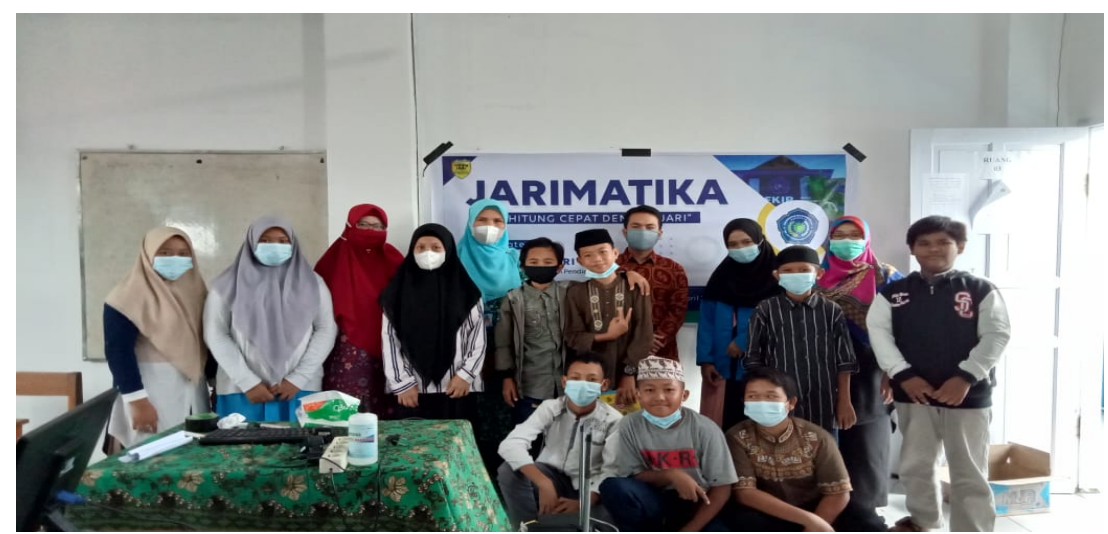

Gambar 2. Sesi Foto Bersama Peserta Didik, Guru Mapel dan Kepsek Setelah Kegiatan Usai

Kegiatan akhir yang dilakukan oleh tim pengabdi adalah membagikan angket respon peserta didik terhadap kegiatan pelatihan yang telah mereka ikuti. Adapun hasil analisis angket tersebut adalah sebagai berikut (Lihat Tabel 1). 
Tabel 1. Respon Peserta Didik terhadap Pelatihan Jarimatika

\begin{tabular}{|c|c|c|c|c|c|c|}
\hline Pernyataan & \multicolumn{3}{|c|}{ Frekuensi } & \multicolumn{3}{|c|}{ Persentase } \\
\hline $\begin{array}{l}\text { Cara menghitung } \\
\text { penjumlahan }\end{array}$ & Sulit & Mudah & $\begin{array}{l}\text { Sangat } \\
\text { Mudah }\end{array}$ & Sulit & Mudah & $\begin{array}{l}\text { Sangat } \\
\text { Mudah }\end{array}$ \\
\hline $\begin{array}{l}\text { perkalian } \\
\text { denganjarimatika }\end{array}$ & 1 & 3 & 6 & $10 \%$ & $30 \%$ & $60 \%$ \\
\hline $\begin{array}{l}\text { Saat menghitung } \\
\text { penjumlahan } \\
\text { pengurangan dan }\end{array}$ & $\begin{array}{l}\text { Tidak } \\
\text { Senang }\end{array}$ & Senang & $\begin{array}{l}\text { Sangat } \\
\text { Senang }\end{array}$ & $\begin{array}{l}\text { Tidak } \\
\text { Senang }\end{array}$ & Senang & $\begin{array}{l}\text { Sangat } \\
\text { Senang }\end{array}$ \\
\hline $\begin{array}{l}\text { perkalian dengan } \\
\text { jarimatika, saya } \\
\text { merasa }\end{array}$ & - & 4 & 6 & $0 \%$ & $40 \%$ & $60 \%$ \\
\hline $\begin{array}{l}\text { Menghitung } \\
\text { penjumlahan } \\
\text { pengurangan dan }\end{array}$ & $\begin{array}{l}\text { Lebih } \\
\text { Cepat }\end{array}$ & $\begin{array}{l}\text { Sama } \\
\text { Saja }\end{array}$ & Lambat & $\begin{array}{l}\text { Lebih } \\
\text { Cepat }\end{array}$ & Sama Saja & Lambat \\
\hline $\begin{array}{l}\text { perkalian dengan } \\
\text { jarimatika }\end{array}$ & 8 & 2 & 0 & $80 \%$ & $20 \%$ & $0 \%$ \\
\hline $\begin{array}{l}\text { Cara yang } \\
\text { digunakan pada } \\
\text { metode jarimatika }\end{array}$ & $\begin{array}{l}\text { Menan } \\
\text { tang }\end{array}$ & $\begin{array}{l}\text { Menarik } \\
\text { \&Mudah }\end{array}$ & $\begin{array}{c}\text { Sulit } \\
\text { Dipahami }\end{array}$ & $\begin{array}{l}\text { Menanta } \\
\text { ng }\end{array}$ & $\begin{array}{l}\text { Menarik\&M } \\
\text { udah }\end{array}$ & $\begin{array}{l}\text { SulitDipah } \\
\text { ami }\end{array}$ \\
\hline ini lebih & 3 & 7 & 0 & $30 \%$ & $70 \%$ & $0 \%$ \\
\hline
\end{tabular}

Berdasarkan Tabel 1, terlihat bahwa pada umumnya peserta didik memberikan respon yang positif terhadap pelatihan jarimatika ini. Beberapa peserta didik menganggap bahwa jarimatika merupakan cara yang menantang untuk menentuka hasil penjumlahan, pengurangan dan perkalian dasar. Selain itu $80 \%$ peserta didik berpendapat bahwa menghitung penjumlahan, pengurangan dan perkalian dengan menggunakan jarimatika jauh lebih cepat dinadingkan dengan metode konvensional. Perolehan persentase ini jauh dari target yaitu 70\%. Maka dari itu, pengabdi menyimpulkan bahwa, penerapan metode jarimatika dalam melakukan operasi bilangan sangat efektif.

\section{Kesimpulan}

Kegiatan pelatihan jarimatika untuk peserta didik di UPT SMP Muhammadiyah 1 Makassar tepatnya di jalan Maccini sawah I No.12, Maccini Kelurahan Rappocini Kota Makassar pada hari kamis Tanggal 01 April 2021 membuat peserta sangat antusias mempelajari operasi hitung matematika. Kegiatan ini terlaksana dengan baik dan diikuti sebanyak 10 peserta didik. Dari hasil seluruh rangkaian kegiatan ini dapat disimpulkan bahwa: (1) peserta didik memahami formasi jari tangan dan aturan penjumlahan, pengurangan dan perkalian dengan menggunakan jarimatika; (2) peserta didik merasa lebih mudah dan lebih cepat dalam menghitung operasi dasar dengan menggunakan jarimatika; (3) peserta didik memberikan respon positif terhadap kegiatan ini. Secara umum kegiatan ini memberikan pengetahuan baru kepada peserta didik tentang salah satu metode cepat dan menyenangkan untuk melakukan operasi hitung dasar terutama pada operasi perkalian. Berdasarkan hal tersebut tim pengabdi menyarankan kepada guru-guru untuk memperkenalkan metode jarimatika sebagai salah satu alternatif untuk membuat siswa lancar dalam menjumlahkan, mengurangkan dan mengalikan operasi hitung matematika. Untuk kegiatan pengabdian selanjutnya, Tim pengabdi memberikan rekomendasi agar guru-guru siap menerapkan jarimatika dalam proses belajar 
mengajar agar supaya siswa makin bersemangat dalam belajar matematika serta untuk mengatasi kekhawatiran akan tidak dapat terselesaikannya semua materi yang harus diberikan disekolah, pemberian metode jarimatika dapat diberikan pada jam tambahan disore hari ataupun dilakukan dirumah dengan bantuan para orang tua siswa. Bagi pengabdi lainnya disarankan untuk meneliti ulang permasalahan ini dengan jangkauan materi yang lebih luas dan menggunakan subjek yang lebih banyak untuk mengklarifikasi hasil penelitian ini

\section{Ucapan Terimakasih}

Kegiatan pengabdian ini dapat terlaksana dengan baik berkat adanya dukungan dan kerjasama serta partisipasi dari berbagai pihak. Oleh karena itu tim pengabdi mengucapkan banyak terimakasih kepada Lembaga Penelitian Pengembangan dan Pengabdian kepada Masyarakat (LP3M) Universitas Muhammadiyah Makassar yang telah memberikan fasilitas dalam pelaksanaan kegiatan, terimakasih kepada Bapak Dekan FKIP dan Ketua Prodi Pendidikan Matematika Universitas Muhammadiyah Makassar, kepada Kepala Sekolah UPT SMP Muhammadiyah 1 Makassar tepatnya di jalan Maccini sawah I No.12, Maccini Kelurahan Rappocini Kota Makassar selakumitra, guru mata pelajaran matematika dan pesertadidikUPT SMP Muhammadiyah 1 Makassar yang berpartisipasi dalam pengabdian ini, para mahasiswa bimbingan Program Pemantapan Profesi Keguruan (P2K) yang telah siap berkolaborasi dengan kami berdua selaku dosen pembimbing yang melakukan pengabdian serta seluruh pihak yang tidak sempat kami sebutkan satu persatu dalam membantu dan berpartisi dalam kegiatan pengabdian ini.

\section{Referensi}

Bimbingan belajar brilian. (2019, Februari 17). Cara Perkalian Jaritmatika dilengkapi gambar. https://bimbelbrilian.com/cara-perkalian-jarimatika-dilengkapi-gambarperkalian-bilangan-6-sampai-9/

Bobi Saputra. 2019. Pengaruh Jarimatika Terhadap Hasil Belajar Matematika Siswa Kelas III Di Madrasah Ibtidaiyyah al Islam Kota Bengkulu.

Erni Ekafitria Bahar. 2021. Pelatihan Jarimatika Sebagai Cara Mudah Menghafal Perkalian Dasar Di UPT SPF SDN 124 Batuasang https://www.dmijournals.org/jai/issue/view/6

Jarimatika. (2021). In Wikipedia bahasa Indonesia, ensiklopedia bebas. https://id.wikipedia.org/w/index.php?title=Jarimatika\&oldid=18619303

Sudan. 2013. Jaritmatika Penjumlahan Dan Pengurangan. http://pelajarimatematika.blogspot.com/2013/12/jarimatika-penjumlahan-danpengurangan.html

Syah, Muhibbin. 2010. Psikologi Pendidikan Dengan Pendekatan Baru.Bandung:PT Remaja Rosdakarya. 